\title{
PROCEEDINGS OF CBU
}

\section{CBU International Conference Proceedings 2016:}

\section{Innovations in Science and Education}

Editors:

Petr Hájek

Tavleen Sahota

Mary-Anne Jones

23-25 March 2016

Prague, Czech Republic

Organized by

Central Bohemia University, CBU, o.p.s., Prague, Czech Republic

Unicorn College s.r.o., Prague

Publisher

Central Bohemia University, CBU, o.p.s., Prague, Czech Republic

Proceedings of CBU 1805-9961, Vol. 4

Central Bohemia University is a nonprofit private university.

www.cbuni.cz

International Conference on Innovations in Science and Education 2016:

edited by Petr Hájek, Tavleen Sahota, Mary-Anne Jones, Proc. of CBU Vol. 4, E-ISSN 1805-9961 (Online).

http://dx.doi.org/10.12955/cbup.v4.875 
As this is a serial book published annually, it has both ISSN and ISBN. ISSN links to whole series of proceedings based on CBU International Conferences while ISBN links to this specific issue in 2015. Each article has also its own unique permanent DOI number which is located on the first page. A digital object identifier (DOI) is a unique alphanumeric string to identify content and provide a persistent link to its location on the internet. All DOI numbers begin with a 10 and contain a prefix and a sufix separeted by a slash. The prefix is number of four or more digits assigned to organizations; the sufix is assigned by the publisher. All articles were peer reviewed.

Please use the following format to cite material from this book:

Author, A., A. \& Author, B., B. (2016). TITTLE OF PAPER. CBU International Conference

Proceedings, 4. doi: Article DOI.

E-ISBN 978-80-88042-04-4 (Online)
E-ISSN 1805-9961 (Online)

Published by

CBU, o.p.s.

Pod Vodárenskou věží 4,

18200 Praha 8,

Czech Republic

September 16, 2016

CBU International Conference Website

www.cbuic.cz,info@cbuni.cz

www.journals.cz

Publication of record for individual papers is online in the CBU Digital Library: www.journals.cz. This website is used to distribute the articles into various databases. For citing online articles please use E-ISSN (Online ISSN).

Copyright information:

Authors retain copyright and grant the journal right of first publication with the work simultaneously licensed under a Creative Commons Attribution License 3.0 (CC BY 3.0) that allows others to share the work with an acknowledgement of the work's authorship and initial publication in this journal.

Authors are able to enter into separate, additional contractual arrangements for the non-exclusive distribution of the journal's published version of the work (e.g., post it to an institutional repository or publish it in a book), with an acknowledgement of its initial publication in this journal.

Authors are permitted and encouraged to post their work online (e.g., in institutional repositories or on their website) prior to and during the submission process, as it can lead to productive exchanges, as well as earlier and greater citation of published work (See The Effect of Open Access).

\section{The conference Keynote speakers:}

David Hartman, Unicorn College, Academy of Sciences of the Czech Republic and Charles University in Prague

Jiř́ Šolc, Central Bohemia University, Prague

Gunther Kletetschka, Charles University in Prague, Academy of Sciences of the Czech Republic

Mária Bohdalová, Comenius University in Bratislava 


\section{INTRODUCTION}

We had the great honor of organizing the CBU International Conference 2016 (CBUIC 2016) on Innovations in Science and Education in Prague the Capital of the Czech Republic. It was truly a great pleasure for us to greet a lot of participants from many different countries attending CBUIC 2016! We firmly believe that the conference will become an important international event in the field of crossindustry discussion about innovations in Education and Science.

CBUIC 2016 was organized by Central Bohemia University and Unicorn College, Prague, Czech Republic. Proceedings were published by Central Bohemia University.

There were 139 papers accepted for presentation at CBUIC 2016, contributed by over 313 authors (more than twice the number from previous year) from 28 countries. We had four plenary speeches and several well-known scientists and experts, to give invited talks at different sessions.

The purpose of CBUIC 2016 was to provide a forum for the participants to report and review innovative ideas, with up-to-date progress and developments, and discuss the novel approaches to application in the field of their own research areas and discuss challenges of doing science and innovating education approaches.

We sincerely hope that the exchange of ideas on doing research, science and improving education will help the participants on one hand, and international cooperation sharing the common interest will be enhanced on the other hand.

On behalf of the Organization Committee of CBUIC 2016, we would like to heartily thank our colleagues for all they have done for the conference. We would also like to thank the authors for their contribution to the proceedings; the participants and friends of CBUIC 2016, for their interest and efforts in helping us to make the conference possible. Also to the Editorial boards for their effective work and valuable advice, especially the CBUIC 2016 Secretariat and the CBU staff, for their tireless efforts and outstanding services in preparing the conference and publishing the Proceedings.

Petr Hájek, Central Bohemia University

David Hartman, Unicorn College

Conference chairs 


\section{TABLE OF CONTENTS}

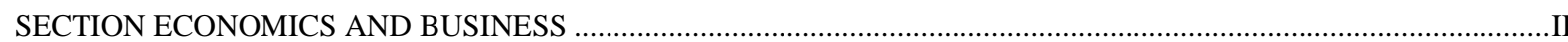

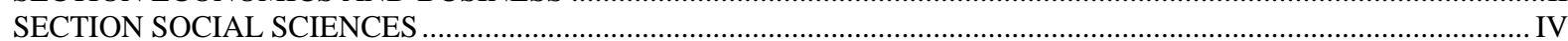

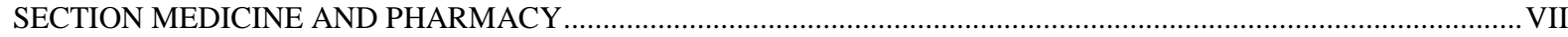

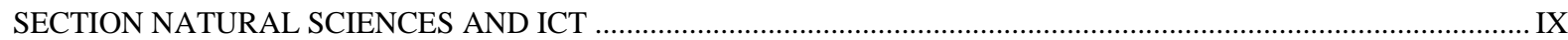

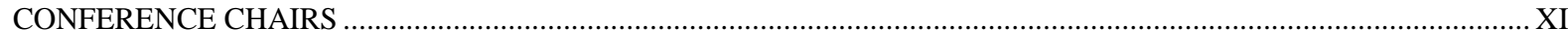

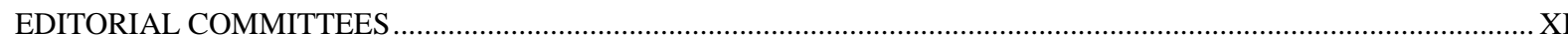

\section{ECONOMICS AND BUSINESS}

MODERN ENTREPRENEURSHIP AS A FACTOR FOR SUCCESS IN THE OPERATION OF TOURISM ENTERPRISES

Kiril Postolov, Marija Magdinceva Sopova, Lidija Pulevska Ivanovska, Tanja Angelkova Petkova, Saso

JosIMOVSKI

http://dx.doi.org/10.12955/cbup.v4.735

INNOVATIVE METHODS OF MARKETING MANAGEMENT OF LUXURY BRANDS FOR EXAMPLE

GUCCI'S COLLABORATION WITH THE FIAT COMPANY

ANASTAZJA MAGDALENA KASZTALSKA

http://dx.doi.org/10.12955/cbup.v4.736

CONSUMER BEHAVIOUR DURING ONLINE GROCERY SHOPPING

10-13

GABRIELA HANUS

http://dx.doi.org/10.12955/cbup.v4.737

TRANSFORMATIONAL LEADERSHIP AND TRUST: A CASE STUDY

ADRIANA ZAHARIA, CARMEN-AIDA HUȚU

http://dx.doi.org/10.12955/cbup.v4.738

DEVELOPING RELATIONS WITH CUSTOMERS: PRESENTATION OF DIFFERENT VIEWPOINTS 21-25

ALENA PIKNOVÁ

http://dx.doi.org/10.12955/cbup.v4.739

AN EMPIRICAL VIEW ON VALUE THEORY AND VALUE-BASED MANAGEMENT 26-35

MARIUS COSTIN DARABAN

http://dx.doi.org/10.12955/cbup.v4.740

INDICATORS OF ENTERPRISE OPERATING ACTIVITIY AND LEVELS OF ITS ECONOMIC

SECURITY

ALINA IANIOGLO

http://dx.doi.org/10.12955/cbup.v4.741

KNOWLEDGE-INTENSIVE BUSINESS SERVICES AS IMPORTANT SERVICES FOR INNOVATION

AND ECONOMIC GROWTH IN SLOVAKIA

TATIANA ČREJOVÁ, MARIO Al KASSIRI http://dx.doi.org/10.12955/cbup.v4.742

HEAVY METALS IN WATERS, PENETRATING THE FOOD, ECOSYSTEMS AND THE ECONOMY OF KOSOVO

Adem Dreshaj, Bedri Millaku, Afrim Selimaj, Fidan FeKa, Muhamet Kelmendi

http://dx.doi.org/10.12955/cbup.v4.743

THE INTEGRATION OF BUSINESS MODELS AS PART OF PRE-MERGER AND ACQUISITIONS IN THE POLISH SECTOR OF MANAGEMENT INFORMATION SYSTEMS

JOLANTA WARTINI-TWARDOWSKA, ZBIGNIEW TWARDOWSKI

http://dx.doi.org/10.12955/cbup.v4.744

DYNAMICS AND EFFICIENCY OF EVENTS TOURISM, FACTORS IN GLOBAL ECONOMIC GROWTH 73-78 Raluca Georgiana Stoian, Manuela Liliana Muresan http://dx.doi.org/10.12955/cbup.v4.745

ECONOMIC CRISIS AND POLANYI'S DOUBLE MOVEMENT. 79-87

ÖZGÜR ÜSENMEZ, LEVENT DUMAN

http://dx.doi.org/10.12955/cbup.v4.746

OWNERSHIP STABILIZATION OF SAVINGS BANKS BY FOUNDATIONS 88-91

HOLGER BLISSE

http://dx.doi.org/10.12955/cbup.v4.747

THE ACCOUNTING STANDARDS AND FINANCIAL REPORTING IN ALBANIA 92-97

REZARTA SHKURTI, BRUNILDA DURA

http://dx.doi.org/10.12955/cbup.v4.748

PROCEEDINGS OF CBU INTERNATIONAL CONFERENCE Vol. 4

MARCH 23-25, 2016, PRAGUe, CZECH RePUBLIC 
DETERMINANTS OF EFFICIENCY IN ALBANIAN BANKING INDUSTRY; AN EMPIRICAL

DIAGNOSIS

ELONA SHEHU

http://dx.doi.org/10.12955/cbup.v4.749

USING MULTILEVEL MODELING TECHNIQUES FOR SOCIAL AND ECONOMIC MONITORING....... 106-109 STANISLAV DUby KIVSKYI, SERGIY Holub

http://dx.doi.org/10.12955/cbup.v4.750

INTELLECTUAL ENTREPRENEURSHIP AS CAPITALIZATION OF KNOWLEDGE IN INNOVATIVE ENVIRONMENTS AND PATTERNS OF ITS EMERGENCE 110-120 IRINA SENNIKOVA

http://dx.doi.org/10.12955/cbup.v4.750

CONSUMER MISBEHAVIOR IN TOURISM MARKET.

MARTA GRYBŚ-KABOCIK, AGNIESZKA MARIE

http://dx.doi.org/10.12955/cbup.v4.751

ORGANIZATIONAL KNOWLEDGE ACQUISITION - STRATEGIC OBJECTIVE OF ORGANIZATION.126-131 Alina LuCA, Luminita MiHAEla LuPU, IONUT VioRel HeRGHILIGIU

http://dx.doi.org/10.12955/cbup.v4.753

IS THE GLOBAL COMPETITIVENESS INDEX INFORMATIVE?

132-141

MENBERE WORKIE TIRUNEH, EDITA HEKELOVÁ

http://dx.doi.org/10.12955/cbup.v4.754

BANK CREDIT TO THE PRIVATE SECTOR BEFORE, DURING AND AFTER THE CRISIS - EVIDENCE FROM CESEE COUNTRIES 142-153

RILIND ADEMI

http://dx.doi.org/10.12955/cbup.v4.755

CREDIT AND ECONOMIC REGENERATION AFTER THE FINANCIAL CRISIS IN CESEE. 154-163

BEKIM STAFAI, RILIND ADEMI

http://dx.doi.org/10.12955/cbup.v4.756

BUSINESS CAPABILITIES AND HR KNOWLEDGE' AS THE CRITICAL FACTOR OF DUE DILIGENCE IN PRE-ACQUISITION PHASE 164-171

ALEN SACEK, BAIBA SAVRINA

http://dx.doi.org/10.12955/cbup.v4.757

CREDIT INDEBTEDNESS AS CONVERGENCE CATALYST OF ECONOMIC REGENERATION IN THE V4 COUNTRIES 172-178

MARTIN HUDEC

http://dx.doi.org/10.12955/cbup.v4.758

PROBLEMS IN FORMING COST ESTIMATES FOR CONSTRUCTION INDUSTRY 179-186 SERgey Oparin, Nikolay ChePaChenKo, Marina YudenKo

http://dx.doi.org/10.12955/cbup.v4.759

THE IMPACT OF BUSINESS ENVIRONMENT ON REGIONAL DISPARITIES

187-191

VIKTOR ŠOLTÉS, KATARÍNA REPKOVÁ ŠTOFKOVÁ

http://dx.doi.org/10.12955/cbup.v4.760

VARIOUS APPROACHES TO SOLVE UNCAPACITATED FIXED-CHARGE FACILITY LOCATION PROBLEM ON POSTAL NETWORK

JOZEF ŠTEFUNKO, RADOVAN MADLEŇÁK

http://dx.doi.org/10.12955/cbup.v4.761

CUSTOMER LOYALTY PROGRAM AS A TOOL OF CUSTOMER RETENTION: LITERATURE

REVIEW

MAGDALENA HOFMAN-KOHLMEYER

http://dx.doi.org/10.12955/cbup.v4.762

ECONOMIC EVALUATION OF HEALTH CARE UTILIZATION IN THE SLOVAK REPUBLIC 204-213

ZuZana Haramiová, Ivona MaloveckÁ, ZuZana KoblišKová, Daniela MinÁRIKová, Viliam Foltán

http://dx.doi.org/10.12955/cbup.v4.763

THE EFFECTS OF OWNERSHIP CONCENTRATION ON PERFORMANCE OF PAKISTANI LISTED COMPANIES

NOUMAN AfGAN, KLAUS GUGLER, ROBERT KunSt

http://dx.doi.org/10.12955/cbup.v4.764 
A FACTORIAL ANALYSIS OF INFORMACION SOURCES THAT INFLUENCE UNIVERSITY CHOICE

IN ALBANIA

ELFRIDA MANOKU

http://dx.doi.org/10.12955/cbup.v4.765

ESTIMATING THE HEDGE RATIOS

MÁRIA BoHDAlOVÁ, Michal GREGUŠ

http://dx.doi.org/10.12955/cbup.v4.874

MANAGEMENT PERSPECTIVE AND DEVELOPMENT OF SMALL AND MEDIUM ENTERPRISES IN KOSOVO 235-239

RifAT HoxHa, HAMdi Hoti, Remzi AHMETI

http://dx.doi.org/10.12955/cbup.v4.869

KNOWLEDGE AS A KEY RESOURCE CONTRIBUTING TO THE DEVELOPMENT OF ECO-

INNOVATIONS BY COMPANIES-SUPPLIERS OF ENVIRONMENTALLY SOUND TECHNOLOGIES.... 240-247

MaGdaLENA MARCZEWSKA

http://dx.doi.org/10.12955/cbup.v4.806

MOBILE 5G TECHNOLOGY ADOPTION INVESTMENT TIMING DECISION MAKERS CLUSTERING

AND WILLINGNESS TO INVEST UNDER VOLATILE DEMAND CHANGES .248-256

SAULIUS ADAMAUSKAS, RYTIS KRUŠINSKAS

http://dx.doi.org/10.12955/cbup.v4.853

\section{SOCIAL SCIENCES}

EFFECTS OF URBANISM ON MALACOFAUNA (NITRA, SLOVAKIA)

257-261

BARBORA HOLIENKOVÁ, ZUZANA KRUMPÁLOVÁ

http://dx.doi.org/10.12955/cbup.v4.766

ADAPTATION TO THE INFORMATION SOCIETY OF PEOPLE WITH DISABILITIES IN SLOVAKIA .262-275

ANNA ONDREJKOVÁ

http://dx.doi.org/10.12955/cbup.v4.767

SHOULD WE INCLUDE TERMS IN READABILITY FORMULAS OF SLAVONIC TEXTS? 276-282

IVANA ŠKORECOVÁ, ABA TELEKI, L'UBOMÍR ZELENICKÝ

http://dx.doi.org/10.12955/cbup.v4.768

THE POSSIBILITIES OF USING BLENDED LEARNING IN FIRE SAFETY EDUCATION 283-286

Jozefína Drotárová, Danica KačíKová, Miroslav Kelemen, MiKuláš Bodor

http://dx.doi.org/10.12955/cbup.v4.769

CULTURAL HISTORICAL ACTIVITY THEORY: EXPLORING PRINCIPALS' INSTRUCTIONAL

LEADERSHIP 287-291

FULYA DAMLA KENTLI

http://dx.doi.org/10.12955/cbup.v4.770

EDUCATION BY THEATRE PROJECT (2010 - 2014)

292-303

DAGMAR INŠTITORISOVÁ

http://dx.doi.org/10.12955/cbup.v4.771

THE HIERARCHY AND TYPOLOGY OF FAMILY SOCIAL SUPPORT NETWORKS AND THEIR IMPLICATIONS FOR SOCIAL SERVICES

IVANA LOUČKOVÁ, AliCE GOJOVA

http://dx.doi.org/10.12955/cbup.v4.772

A DIDACTIC PERSPECTIVE ON THE FALSE TREATY OF MANIPULATION - WRITTEN BY ANA

BLANDIANA

311-317

FLORINA - IRINA DIMA

http://dx.doi.org/10.12955/cbup.v4.773

YOUNGSTER'S ATTITUDES TO SCHOOL-BASED PREVENTION PROGRAMS FOCUSED ON DRUG

ABUSE PREVENTION 318-324

BARBORA ODRASKOVA, MichAL KOZUBIK, LUKAS ODRASKA

http://dx.doi.org/10.12955/cbup.v4.774

SHAPING SWIFT'S EXPRESSIVENESS THROUGH THE TRANSLATION OF HIS METAPHORS IN ALBANIAN LANGUAGE.

Alma KARASALIU

http://dx.doi.org/10.12955/cbup.v4.775 
THE IMPORTANCE OF ELEMENTS OF ACTIVE LISTENING IN DIDACTIC COMMUNICATION: A STUDENT'S PERSPECTIVE.

Flavia MĂLuREANU, LuIZA ENACHI-VASLUIANU

http://dx.doi.org/10.12955/cbup.v4.776

MODERN LANGUAGE TRAINING METHODS AND THEIR APPLICATION IN CZECH AND SLOVAK BUSINESSES: A LITERATURE REVIEW 336-339

ADAM DÉKÁNY

http://dx.doi.org/10.12955/cbup.v4.777

FAIR TRADE AS A TOOL OF CORPORATE SOCIAL RESPONSIBILITY 340-345

KATARÍNA MORAVČíKOVÁ, ElENA GREGOVÁ

http://dx.doi.org/10.12955/cbup.v4.778

ARTS BASED INITIATIVES AS A HOLISTIC SOLUTION IN BUSINESS EDUCATION 346-359

JEL̨ENA MALEŠKO, OLGA TJURDJU

http://dx.doi.org/10.12955/cbup.v4.779

ALBA IULIA-LUMEA NOUĂ SITE (ROMANIA): HISTORICAL EVOLUTION FROM NEOLITHIC SETTLEMENT TO A MODERN RECREATION AREA $360-366$

IOANA BORCA, MiHAi Gligor, CORNEL TATAI-BALTĂ

http://dx.doi.org/10.12955/cbup.v4.780

SEARCHING FOR WAYS OF IMPROVING TEENAGERS' TOLERANCE: DETERMINATION BY MULTIETHNIC ENVIRONMENT 367-371

TATIANA VORONCHENKO, NINA VINOGRADOVA

http://dx.doi.org/10.12955/cbup.v4.781

DEFINING CRITERIA FOR EVALUATING CULTURAL AND DIALOGIC DEVELOPMENT OF BILINGUAL PRESCHOOLERS

Alexandra UlzytuyeVa, TAtiana Voronchenko, Nina VinOGRAdova

http://dx.doi.org/10.12955/cbup.v4.782

THE CAUSES OF LOSING TRUST IN THE GOVERNMENT IN RECENT YEARS IN ALBANIA 378-384 ANISA PRODA http://dx.doi.org/10.12955/cbup.v4.783

RELATIVE CLAUSES FROM ENGLISH TO ALBANIAN 385-391

SuEla KoÇA, VASILIKA POJANI

http://dx.doi.org/10.12955/cbup.v4.784

INNOVATIVE TRENDS IN GEOGRAPHY FOR PUPILS WITH MILD INTELLECTUAL DISABILITY .... 392-398 MONIKA ŚulovsKá, Alica VANČOvá http://dx.doi.org/10.12955/cbup.v4.785

PUBLIC FUNDING OF CIVIL SOCIETY ORGANIZATIONS IN LATIN AMERICA: HOW DO WE

EVALUATE PROFITABILITY? $399-402$

STEPHEN JOHN BEAUMONT

http://dx.doi.org/10.12955/cbup.v4.786

INTEGRATION IN LATVIA: FLOWS AND EBBS IN NATIONAL AND EUROPEAN CONTEXT 403-407 JURIS ROZENVALDS http://dx.doi.org/10.12955/cbup.v4.787

ABOUT SOME SOCIAL AND HEALTH PROBLEMS OF PERSONS, SEEKING INTERNATIONAL PROTECTION ON THE TERRITORY OF THE REPUBLIC OF BULGARIA 408-413 Hristina Milcheva, Albena Andova, Mariya Dimova http://dx.doi.org/10.12955/cbup.v4.788

MODELS OF STRUCTURES IN DIDACTICS 414-421

STEFAN NIEWITECKI

http://dx.doi.org/10.12955/cbup.v4.789

FACTORS AFFECTING THE CHOICE OF HIGHER EDUCATION INSTITUTIONS BY PROSPECTIVE STUDENTS IN LATVIA 422-430

NADEZDA RIKA, JANA ROZE, IRINA SENNIKOVA

http://dx.doi.org/10.12955/cbup.v4.790

RISK ANALYSIS IN THE PROCESS OF PREPARING AND CREATING A MUNICIPAL PLAN 431-436

TOMÁŠ PAVLENKO, JÁN DVORSKÝ

http://dx.doi.org/10.12955/cbup.v4.791 
TOMÁŠ PAVLENKO, VERONIKA MitaŠOVÁ, JÁN HAVKO

http://dx.doi.org/10.12955/cbup.v4.793

INTRODUCING GRAMMAR LEARNING STRATEGIES IN A2 AND B1 CLASSES OF ENGLISH AS A FOREIGN LANGUAGE: AN ALBANIAN CASE STUDY 444-450

Benita Stavre, ANXHELA PASHKo

http://dx.doi.org/10.12955/cbup.v4.795

INTERNATIONAL LEGAL COOPERATION IN SPHERES OF CULTURE - IMPORTANT PART OF INTERNATIONAL RELATIONS 451-453

NURIDDIN MAMAJONOV

http://dx.doi.org/10.12955/cbup.v4.796

TURKEY BETWEEN SECULARIZATION AND PIETISM

TAHA NIYAZI KARACA

http://dx.doi.org/10.12955/cbup.v4.797

ECO-TRAILS - AN OPPORTUNITY FOR LEARNING OUTDOORS CLOSE TO NATURE

458-463

Krasimir Todorov, Slaveya Petrova, Bogdan Nikolov, Ivanka Dimitrova-Dyulgerova, Delka

KARAGYOZOVA-DILKOVA

http://dx.doi.org/10.12955/cbup.v4.798

HUMOR STYLES IN SOCIALLY MALADJUSTED GIRLS AND BOYS: A RESILIENCE PERSPECTIVE464-470 ANNA KARŁYK-ĆWIK

http://dx.doi.org/10.12955/cbup.v4.799

ROMANIA VERSUS BULGARIA: A SHORT ANALYSIS OF THE COMPETITIVENESS OF SEASIDE TOURISM

Mihai Costea, Cristian-Valentin Hapenciuc, Gabriela Arionesei

http://dx.doi.org/10.12955/cbup.v4.800

PERCEIVED PARENTING STYLES AND SCHOOL ANXIETY IN PREADOLESCENTS 483-488

SIMONA BUTNARU

http://dx.doi.org/10.12955/cbup.v4.801

VIOLENCE IN PARTNERSHIP AND PERSISTING PROBLEMS OF ASSISTANCE 489-498

HERMÍNA MAREKOVÁ

http://dx.doi.org/10.12955/cbup.v4.802

THE PECULIARITIES OF SOCIAL PERCEPTION IN THE CONTEXT OF INFORMATION-

PSYCHOLOGICAL WARFARE

499-504

NANE ZEYNALYAN

http://dx.doi.org/10.12955/cbup.v4.803

LAND USE INDICES FROM SMMS DATA IN WESTERN THAILAND $505-508$

UTEN THONGTIP

http://dx.doi.org/10.12955/cbup.v4.804

AN AMICABLE AGREEMENT OR ANOTHER FORM OF DEBT RESTRUCTURING IN INSOLVENCY PROCEDURE FOR INDIVIDUALS IN LATVIA $509-514$

RENATA KONOPECKA

http://dx.doi.org/10.12955/cbup.v4.805

THE IMPORTANCE OF CSR IMPLEMENTATION $.515-519$

ANNA KRIŽANOVÁ, L'UBICA GAJANOVÁ

http://dx.doi.org/10.12955/cbup.v4.807

TAXONOMIES OF PHYSICS PROBLEMS IN PHYSICS EDUCATION

$.520-525$

MONIKA HANÁKOVÁ, DANIEL KLUVANEC

http://dx.doi.org/10.12955/cbup.v4.808

SCIENCE COMMUNICATION ROLE IN DEVELOPMENT OF COOPERATION BETWEEN UNIVERSITY AND INDUSTRY IN LA

JUSTīNe VỊ̄̄E

http://dx.doi.org/10.12955/cbup.v4.809

USER ADOPTION OF MANDATORY E-GOVERNMENT SYSTEMS: NOTARIAL SYSTEM IN ALBANIA, AN EMPIRICAL ANALYSE

AGIM KASAJ

http://dx.doi.org/10.12955/cbup.v4.810 
THEORETICAL AND EMPIRICAL FOUNDATION FOR INTEGRATION OF LANGUAGE EDUCATION IN CLASSES OF OTHER DISCIPLINES

DAIVA JAKAVONYTĖ-STAŠKUVIENÉ

http://dx.doi.org/10.12955/cbup.v4.811

EVALUATING BASIC EDUCATION CURRICULUM FROM A GENDER PERSPECTIVE: ADDRESSING GENDER STEREOTYPES IN ELEMENTARY SCHOOL TEXTBOOKS

ERIADA ÇELA

http://dx.doi.org/10.12955/cbup.v4.812

WORK STRESS AND SUBJECTIVE/PSYCHOLOGICAL WELL-BEING OF EMPLOYEES OF STATE HOLDING COMPANY IN TIMES OF CHANGE.

SOLVEIGA BLUMBERGA, SOLVITA VORONOVA

http://dx.doi.org/10.12955/cbup.v4.813

THE CONCEPTUAL STRUCTURE OF PHYSICS TEXTBOOKS FOR SECONDARY SCHOOLS 563-568

PETRA KRÁlikOVÁ, ABA TELEK

http://dx.doi.org/10.12955/cbup.v4.814

MARITAL CONFLICTS RESOLUTION STYLES

$569-572$

HATIXHE ISLAMI

http://dx.doi.org/10.12955/cbup.v4.815

A COMPARATIVE VIEW REGARDING THE TERRITORIAL-ADMINISTRATIVE REFORMS AND LOCAL GOVERNANCE IN POLAND AND CZECH REPUBLIC

AURORA NDREU

http://dx.doi.org/10.12955/cbup.v4.816

TEACHER'S ATTITUDE TOWARDS THE INCLUSION OF STUDENTS WITH DISABILITIES IN REGULAR SCHOOLS.

ROVENA LIKA

http://dx.doi.org/10.12955/cbup.v4.817

AN EFFECTIVE ENGLISH CLASS WITH APPROPRIATE TECHNIQUES AND STRATEGIES $583-590$

VAHIDIJE KADIU, TOMI TRESKA

http://dx.doi.org/10.12955/cbup.v4.818

MEDIA ARCHITECTURE AND INTERACTIVE ART INSTALLATIONS STIMULATING HUMAN INVOLVEMENT

AND ACTIVITIES IN PUBLIC SPACES

KATARZYNA URBANOWICZ, LUCYNA NYKA

http://dx.doi.org/10.12955/cbup.v4.819

INTERACTION BETWEEN BIG DATA AND COMPETITION LAW IN DIGITAL SINGLE MARKET 597-602

ANDRIUS PUKSAS

http://dx.doi.org/10.12955/cbup.v4.850

COLLABORATION MODEL FOR ASEAN UNIVERSITY NETWORK: A CASE STUDY OF PHRANAKHON RAJABHAT UNIVERSITY AND NETWORKING UNIVERSITIES IN ASEAN COUNTRIES 603-607 SUEBWONG KALAWONG

http://dx.doi.org/10.12955/cbup.v4.837

\section{MEDICINE AND PHARMACY}

IMPACT OF CAROTID ENDARTERECTOMY ON COGNITIVE PERFORMANCE AND DEPRESSIVE SYMPTOMS... 608-614 Elina Pucite, Marius Slisers, EviJa Miglane, Dainis Krievins, Renars ERTs, Kristaps JuRJans, ILDZE KRIEVINA http://dx.doi.org/10.12955/cbup.v4.820

CARDIOEMBOLIC STROKE IN LATVIA: PREVENTION AND LONG-TERM OUTCOME 615-62

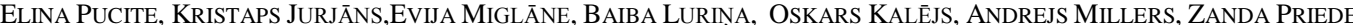

http://dx.doi.org/10.12955/cbup.v4.821

HEALTH BEHAVIORS OF UNDERGRADUATE STUDENTS: A COMPARISON OF PHYSICAL EDUCATION AND TECHNICAL FACULTIES

ALEKSANDRA ROGOWSKA, BOŻENA WOJCIECHOWSKA-MASZKOWSKA, DOROTA BORZUCKA

http://dx.doi.org/10.12955/cbup.v4.822

A CASE REPORT: PKP2 GENE C.1592T>G VARIATION IN HOMOZYGOUS FORM IDENTIFIED IN ARRHYTHMOGENIC RIGHT VENTRICULAR DYSPLASIA PATIENT 631-633

Luize Bidina, Kaspars Kupics, Emma Sokolova, Mihails PaVlovics, Zane Dobele, Linda PiEKuse, Oskars Kalejs

http://dx.doi.org/10.12955/cbup.v4.823

ESTABLISHING IMMUNIZATION SAFETY SURVEILLANCE SYSTEM IN ALBANIA 634-641 IRSIDA MEHMETI, SILVA BINO

http://dx.doi.org/10.12955/cbup.v4.824

FALLS' RISK ANALYSIS OF OLDER PATIENTS IN NURSING DEPARTMENTS: ONE MONTH STUDY 642-646 AGNĖ JAKAVONYTÉ-AKSTINIENĖ, JÜRATĖ MACIJAUSKIENĖ

http://dx.doi.org/10.12955/cbup.v4.825 
MEASURING THE DIELECTRIC PROPERTIES OF TUMOR AND BREAST PHANTOMS USED IN THE MICROWAVE FREQUENCY RANGE

EVA MANIAKOVA, DAGMAR FAKTOROVA

http://dx.doi.org/10.12955/cbup.v4.826

IGG SPECIFIC LEVELS FOR DIPHTHERIA, TETANUS AND PERTUSSIS IN RURAL AND URBAN SAMPLES IN ALBANIA. 652-657

EFTIOLA POJANI, ERIDA NELAJ, AlBAN YLLI

http://dx.doi.org/10.12955/cbup.v4.827

MICROWAVE PROPAGATION IN TOOTH AND DENTAL DEFECT

MARIA PAPEZOVA, DAGMAR FAKTOROVA

http://dx.doi.org/10.12955/cbup.v4.828

HEALTH PROTECTION OF PRISONERS IN THE REPUBLIC OF MACEDONIA

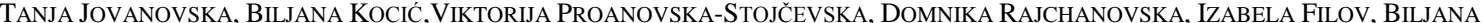

BOGDANOVA

http://dx.doi.org/10.12955/cbup.v4.829

THE RELATION BETWEEN PSYCHOSOCIAL WORK FACTORS AND MUSCULOSKELETAL SYMPTOMS AMONG

VikTORIJA Prodanovska-StojCEVSKa, JoviCA JOVANOVIC, TANJA JOVANOVSKA, DOMNIKA RAJCHANOVSKA, IZABELA FILOV,

BILJANA BOGDANOVA

http://dx.doi.org/10.12955/cbup.v4.830

PROBLEMS OF FAMILIES WITH A CHILD WITH AN INCURABLE DISEASE IN THE CONTEXT OF SPECIAL

EDUCATION

KRISTÍNA NAGYOVÁ, TERÉZIA HARČARÍKOVÁ

http://dx.doi.org/10.12955/cbup.v4.831

PROMOTION HEALTH - EVALUATION OF THE LOCUS OF CONTROL OVER HEALTH

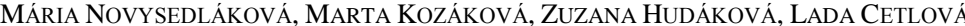

http://dx.doi.org/10.12955/cbup.v4.832

ISSUE OF YOGA ON PHYSICAL AND MENTAL HEALTH

689-692

SILVIA HORVÁTHOVÁ, IVETA PETRÍKOVÁ ROSINOVÁ

http://dx.doi.org/10.12955/cbup.v4.833

THE HIDDEN PICTURE: UNHEALTHY EATING ATTITUDES AND BEHAVIORS IN A NON-CLINICAL POPULATION FROM BULGARIA

RADKA MASSALDJIEVA, DESISLAVA BAKOVA, MARIA SEMERDJIEVA, BoRIS TILOV, EKATERINA RAIKOVA, BIANKA TORNIOVA

http://dx.doi.org/10.12955/cbup.v4.834

STUDY OF KINETIC PARAMETERS AND POSSIBLE INHIBITORY EFFECT ON THE TYROSINASE OF THE

HALOGENATED BOROXINE DIPOTASSIUM TRIOXOHYDROXYTETRAFLUOROTRIBORATE $\mathrm{K}_{2}\left[\mathrm{~B}_{3} \mathrm{O}_{3} \mathrm{~F}_{4} \mathrm{OH}\right]$

MAJA MARASOVIĆ, ZRINKA ČORIĆ, MLADEN MILOŠ, BORIVOJ GALIĆ

http://dx.doi.org/10.12955/cbup.v4.835

THE METHOD OF SPECTRALLY SELECTIVE LASER MUELLER MATRIX POLARIMETRY FOR VERIFICATION

OF ACUTE CORONARY INSUFFICIENCY

OLEH VANCHULIAK, VICTOR BACHINSKIY, ALEXANDER USHENKO

http://dx.doi.org/10.12955/cbup.v4.836

POST-MORTEM INTERVAL ESTIMATION BY CEREBRO-SPINAL FLUID FILMS POLARIZATION IMAGES

OPTICAL STRUCTURE CHANGING

MARTA GARAZDIUK, VIKTOR BACHYNSKIY, OLEG WANCHULIAK, OLEKSANDR GARAZDIUK, ALEKSANDR USHENKO

http://dx.doi.org/10.12955/cbup.v4.838

INFLUENCE OF AGE AND GENDER ON THE STRENGTH OF BLOOD VESSELS

ZYTA KUZBORSKA

http://dx.doi.org/10.12955/cbup.v4.839

INNOVATION AND SIMULATION-BASED TEACHING TECHNIQUE IN PATHOLOGICAL PHYSIOLOGY

LEA KovÁČIKOVÁ, FERDinANd VARGA, EVA KVALTínYOVÁ, JANA PlEVKOVÁ, TOMÁŠ BudAY

http://dx.doi.org/10.12955/cbup.v4.840

HIGHER CTX-M, TEM, AND SHV EXTENDED-SPECTRUM BETA-LACTAMASE PLASMID GENE COMBINATION FREQUENCY IN ESBL PRODUCING KLEBSIELLA PNEUMONIAE COMPARED WITH ESBL PRODUCING

Vita Skuja, Katrīna PeKarska, Aleksejs Derovs, Ludmila Vīksna, Linda Piekuse, Inga KemPa, UnA CAUne, DaCe

RUDZĪTE, AIVARS LEJNIEKS, ANGELIKA KRŪMIN̦A

http://dx.doi.org/10.12955/cbup.v4.841

NEW COMPOUND N1,N1'-(2"-BROMO-2"-CHLOROETHENYL)-BIS-(5-FLUOROURACIL) AS THE ACTIVE ANTITUMOR AGENT FOR SARCOMA 180.

ELENA WELCHINSKA, VALERIIA VILCHYNSKA

http://dx.doi.org/10.12955/cbup.v4.842 
CARBON (II) MONOXIDE AS A SUBJECT FOR POISONS STUDYING OF STUDY ON DISCIPLINE TOXICOLOGICAL CHEMISTRY (CRIMINAL ANALYSIS) AT THE PHARMACEUTICAL DEPARTMENT OF THE NATIONAL MEDICAL UNIVERSITY IN UKRAINE

YAROSLAV TSEKHMISTER, ELENA WELCHINSKA

http://dx.doi.org/10.12955/cbup.v4.843

WORK ABILITY AND PSYCHOLOGICAL WELL-BEING IN HOSPITAL STAFF 750-755

GERGANA SANDEVA, Krasimira KolEVA

http://dx.doi.org/10.12955/cbup.v4.844

AN ARTIFICIAL NEURAL NETWORK DESIGN FOR DETERMINATION OF HASHIMOTO'S THYROIDITIS SUBGROUPS

MEHMET EMIN AKTAN, ERHAN AKDOĞAN, NAMIK ZENGIN, ÖMER FARUK GÜNEY, RABIA EDIBE PARLAR

http://dx.doi.org/10.12955/cbup.v4.845

PRESENT KNOWLEDGE AND EXPERIENCE ON THE STRATEGIES EMPLOYED BY MYCOPLASMA

CONTAMINATION OF THE HUMAN CELL CULTURES

Nevenka Velickova, Misko Milev, Gorgi Sumanov, Biljana Petrova

http://dx.doi.org/10.12955/cbup.v4.846

THE ROLE OF PATIENTS AND MEDICAL SPECIALISTS IN ACHIEVING HIGHER LEVEL OF THERAPY COMPLIANCE- AN EXAMPLE WITH WILLINGNESS TO PARTICIPATE IN CLINICAL TRIALS

SVETOSLAV STOEV, VladimiR ATANASOV, ILKo GETOV

http://dx.doi.org/10.12955/cbup.v4.847

TRAINING OF GERIATRIC SPECIALISTS FOR BUILDING OF COMMUNICATION SKILLS FOR WORK WITH

ELDERLY PEOPLE WITH DISABILITIES

Mariya Dimova, Hristina MiLChEVA, AlBEnA ANDOVA

http://dx.doi.org/10.12955/cbup.v4.848

IMMUNOHISTOCHEMICAL DETECTION OF TETRASPANINS CD81 AND CD9 DISTRIBUTION IN BULL TESTIS AND EPIDIDYMIS 777-781 DENISA LIPCSEYOVÁ, JANA ANTALÍKOVÁ, JANA JANKOVIČOVÁ, PETRA CuPPEROVÁ, LubiCA HoROVSKÁ, KATARÍNA MichaLKOVÁ, MICHAL SIMON

http://dx.doi.org/10.12955/cbup.v4.854

\section{NATURAL SCIENCES AND ICT}

OPEN SOURCE TECHNOLOGY AS AN OPTION FOR AN ALBANIAN UNIVERSITY WITH NO ONLINE PLATFORM: CAN IT BE USED TO IMPROVE LEARNING?

GERDA SULA

http://dx.doi.org/10.12955/cbup.v4.849

ASSESSMENT OF TOXIC METALS IN SEDIMENTS OF MERIÇ, TUNCA AND ERGENE RIVERS BY USING BIOLOGICAL AND ECOLOGICAL RISK INDICES

CEM TOKATLI, YASIN BASTATLI

http://dx.doi.org/10.12955/cbup.v4.851

EXPLORATION OF STYLIZED FACTS IN THE ARTIFICIAL LIFE SYSTEM AVIDA

791-795

SHINTA KOYANO, LUKÁŠ PICHL

http://dx.doi.org/10.12955/cbup.v4.852

CARBOHYDRATE CONTENT IN BULGARIAN AND TURKISH CAROB PODS AND THEIR PRODUCTS 796-802

HAFIZE FIDAN, NADEZHDA PETKOVA, TANA SAPOUNDZHIEVA, ENGIN ISIK ABANOZ

http://dx.doi.org/10.12955/cbup.v4.855

PARAMETRIC DESIGN OF DELTA ROBOT

MERT GÜRGEN, CENK ERYILMAZ, VASFI EMRE ÖMÜRLÜ

http://dx.doi.org/10.12955/cbup.v4.856

WIENER'S BLACK BOX IN THE DYNAMIC IDENTIFICATION OF METALLURGICAL PROCESS WHICH IS BEING AUTOMATED 807-813

ZHANBAy SHUYNSHALYEVYCH UZDENBAYEV, ALIYA ONGARBAYEVA, AIGUL YELEPBERGENOVA

http://dx.doi.org/10.12955/cbup.v4.857

CAR-SHARING: THE IMPACT ON METROPOLITAN SPATIAL STRUCTURES 814-819

PIOTR MAREK SMOLNICKI, JACEK SOŁTYS

http://dx.doi.org/10.12955/cbup.v4.858

EXPERIMENTAL AND ANALYTICAL INVESTIGATION ON EFFECT OF STATOR WINDING TYPE TO EQUIVALENT CIRCUIT PARAMETERS OF INDUCTION MOTORS 820-825

FEVZI KENTLI, AYKUT KENTLI

http://dx.doi.org/10.12955/cbup.v4.859

THERMODYNAMIC PROPERTIES OF PARTIALLY IONIZED HYDROGEN PLASMA 826-831

MARATBEK GABDULLIN, TLEKKABUl RAMAZANOV, TOMIRIS ISMAGAMBETOVA, AINUR KARIMOVA

http://dx.doi.org/10.12955/cbup.v4.860

MODELING AND ANALYSIS OF ABSORBING BOUNDARY CONDITION IN ANTENNA DESIGN 832-839

UMUT OZKAYA, LEVENT SEYFI

http://dx.doi.org/10.12955/cbup.v4.861

PROCEEDINGS OF CBU INTERNATIONAL CONFERENCE VOL. 4

MARCH 23-25, 2016, PRAGUe, CZECH RePUBLIC IX WWW.CBUNI.CZ, WWW.JOURNALS.CZ 
A TOOL FOR EMOTIONAL USER EXPERIENCE ASSESSMENT OF WEB-BASED MEDICAL SERVICES 840-845

ALEXANDER NiKOV, TRAMAINE GUMAIA

http://dx.doi.org/10.12955/cbup.v4.862

COMPARATIVE ANALYSIS OF NON-CONTACT ULTRASONIC METHODS FOR DEFECT ESTIMATION OF COMPOSITES IN REMOTE AREAS.

KUMAR ANUBHAV TIWARI, RENALDAS RAISUTIS

http://dx.doi.org/10.12955/cbup.v4.863

LATHE SELECTION USING ANALYTIC HIERARCHY PROCESS AND INFORMATION AXIOM 852-856

AYKUT KENTLI, SERHAT AKBAS

http://dx.doi.org/10.12955/cbup.v4.864

DESIGN OF HYDROKINETIC ENERGY GENERATION SYSTEM

857-863

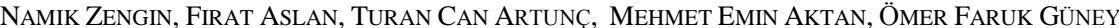

http://dx.doi.org/10.12955/cbup.v4.865

AUTOMATING THE CONSTRUCTION OF SELECTED-RESPONSE ITEMS WITH A TEXT-TO-ITEMS CONVERTER864-872 WOJCIECH MALEC

http://dx.doi.org/10.12955/cbup.v4.866

EMG ONSET DETECTION - A HIDDEN FACTOR 873-878

MATEUSZ MAGDA

http://dx.doi.org/10.12955/cbup.v4.867

SYNTHESIS EVALUATION AND QUANTUM MECHANICAL CHARACTERIZATION OF CYCLOHEXYLAMINE CONTAINING DERIVATIVES OF METHYLXANTHINE 879-887

Maya Georgieva, Javor Mitkov, Lily Peikova, Plamen Peikov, AleXander Zlatkov

http://dx.doi.org/10.12955/cbup.v4.868

MICROSCOPIC MODEL OF KNOWLEDGE INCREASE AND ITS VERIFICATION 888-895

Simona DudÁKOVÁ, Michal BENKO, BORIS LACSNÝ, ABA TELEKI

http://dx.doi.org/10.12955/cbup.v4.872

THE RESEARCH OF DRIVER'S GAZE AT THE TRAFFIC SIGNS 896-899

MARTIN HUDÁK, RADOVAN MADLEŇÁK

http://dx.doi.org/10.12955/cbup.v4.870

RP-HPLC METHOD FOR SIMULTANEOUS DETERMINATION OF METRONIDAZOLE AND OFLOXACIN IN

SYNTHETIC MIXTURE

900-905

VANIA MASLARSKA, BOYKA TSVETKOVA, LILY PEIKOVA, STANISLAV BOZHANOV

http://dx.doi.org/10.12955/cbup.v4.871

AUTOMATIC GENERATION OF ENGLISH LANGUAGE TEST QUESTIONS USING MATHEMATICA.

906-909

ANNA MALINOVA, OLGA RAHNEVA

http://dx.doi.org/10.12955/cbup.v4.794

A METHODOLOGICAL APPROACH FOR IMPLEMENTATION OF ADAPTIVE E-LEARNING

910-917

VALIA ARNAUdOVA, TODORKA TERZIEVA, ASEN RAHNEV

http://dx.doi.org/10.12955/cbup.v4.792 


\section{CONFERENCE CHAIRS}

Petr Hajek, Central Bohemia University, Prague, Czech Republic

David Hartman, Unicorn College, Academy of Sciences of the Czech Republic, Charles University in Prague, Czech Republic

\section{EDITORIAL COMMITTEES}

\section{Editor-in-chief}

Petr Hajek, Vice-rector, Central Bohemia University, Prague, Czech Republic

\section{Editors}

Tavleen Sahota, Central Bohemia University

Mary-Anne Jones, Central Bohemia University

\section{Economics and Business Section Committee}

Petr Hajek, Central Bohemia University, Prague, Czech Republic

Vaidotas Matutis, State Tax Inspectorate, Ministry of Finance, Vilnius (previously also Mount Royal University - Calgary, Alberta, Canada AND Economic Faculty, Mykolas Romeris University, Vilnius), Lithuania

Michal Brožka, Analyst, Raiffeisenbank, and Unicorn College, Prague, Czech Republic

Lukáš Horák, CEO’s Strategic Analyses Department, Ceska Pojistovna Insurance Group Prague, Czech Republic

Tomáš Voplakal, Ernst and Young, Czech Republic

Valentina Shapoval, Department of Corporate Economics, National Mining University Dnepropetrovsk, Ukraine

Jan Vorlíček, Unicorn College and College of Information Management and Business Administration, Prague, Czech Republic

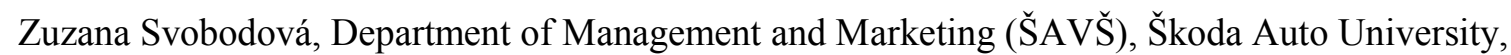
Mladá Boleslav, Czech Republic

Jerome Dumetz, Cross Cultural Management Specialist working in Paris, Prague (Unicorn College), Moscow and Sankt-Peterburg, Clamart, Paris, France

Drahomír Jančík, Institute of Economic and Social History, Faculty of Arts, Charles University, Prague AND Faculty of Business Administration, University of economics in Prague, Czech Republic Jiř́i Kleibl, Unicorn College

Miloš Kaňka, Faculty of Informatics and Statistics University of Economics in Prague AND The College of Polytechnics Jihlava, Czech Republic

Akram Jalal Karim, chairman of the Management Information System Department of College of Business and Finance at Ahlia University, Manama, Bahrain

Kholnazar Amonov, Central Bohemia University, Prague, Czech Republic

Hana Kristová, Senior Auditor, Deloitte, Prague, Czech Republic

Eva Vašková, Victor Pavlik Lawyers LLC.

Viktor Korček, Central Bohemia University AND East-African Project Manager, Prague, Czech Republic

Quang Van Tran, Faculty of Finance and Accounting, University of Economics in Prague, Czech Republic 
Tomáš Pavelka, Faculty of Business Administration, University of Economics in Prague, Czech Republic

Murtaz Kvirkvaia, Dean of the Faculty School of Business and Management, Grigol Robakidze University, Georgia

\section{Medicine and Pharmacy Section Committee}

Jana Staňurová, Fakultät für Biologie und Vorklinische Medizin, Universität Regensburg, Germany

Helena Kristova, Lead clinical research associate, Chiltern International, Prague, Czech Republic

Stanislav Janák, Škrobárny a.s., Pelhřimov, Czech Republic

Ondřej Lešetický, Department of Management (Management in Medicine), University of Economics in Prague, Czech Republic

Izzet Yavuz, Faculty of Dentistry, University of Dicle in Diyarbakir, Turkey

Eva Tůmová, 3rd Department of Medicine - Department of Endocrinology and Metabolism, First Faculty of Medicine, Charles University in Prague and General University Hospital in Prague, Czech Republic

Lucie Pieckova, Faculty of Food and Biochemical Technology Institute of Chemical Technology Prague (VSCHT Chemical University), Czech Republic

Liana Gogiashvili, Head of the Experimental Pathology Department, A. Natishvili Morphology Institute, Tbilisi, Georgia

Ekaterine Chkhartishvili, Human Histology and Embryology Department, AIETI Medical School, David Tvildiani Medical University and No.1 Pediatric Clinic, Tbilisi, Georgia

Eliška Potluková, 3rd Department of Medicine - Department of Endocrinology and Metabolism, First Faculty of Medicine, Charles University in Prague and General University Hospital in Prague, Czech Republic

Nakul Vinod Karkare, Orthopaedic surgeon and biomaterials engineer. Loma Linda, CA, USA

Olga Reshetnikova, Medical Faculty, Lugansk State Medical University, Rubizhne, Ukraine

\section{Social Sciences Section Committee}

Eduard Kubů, Faculty of Arts, Charles University AND University of Economics in Prague AND Unicorn College, Prague, Czech Republic

Eva Vašková, Victor Pavlik Lawyers, Czech Republic

Pavel Král, Faculty of Management, University of Economics in Prague, Czech Republic

Alexander Lesnik, Central Bohemia University, Prague, Czech Republic

Petr Marek, Department of Finance and Business Valuation, Executive board member of Acta Oeconomica Pragensia, University of Economics in Prague, Czech Republic

Arta Musaraj, Academicus-International Scientific Journal, Etc-Entrepreneurship Training Center, Albania

Mikheil Gogatishvili, Programme leader of Public Administration, Social and Political sciences, Grigol Robakidze University, Tbilisi, Georgia

Nino Kemertelidze, Grigol Robakidze University (Heading Scientific Research Management Centre and Center of International Integration), Tbilisi, Georgia

Daniel Tácha, freelance journalist, Prague, Czech Republic 


\section{Natural Sciences Section Committee}

Viktor Goliáš, Institute of geochemistry, mineralogy and mineral resources, Faculty of Science, Charles University in Prague, Czech Republic

Michal Kökörčený, Head of Project Management Department (IT projects), Frederiksgroup AND Unicorn College, Prague, Czech Republic

Y1lmaz Uyaroğlu, Electrical \& Electronics Engineering Department, Engineering Faculty, Sakarya University, Sakarya, Turkey

Ahmet Çifci, Electrical and Energy Department, Burdur Mehmet Akif Ersoy University, Burdur, Turkey

Uğur Erkin Kocamaz, Computer Technologies Department, Uludağ University, Karacabey, Turkey

Bohumil Havrland, Faculty of Tropical AgriSciences, Czech University of Life Sciences, Prague, Czech Republic

Ladislav Torčík, CEO, NanoTrade Ltd., Olomouc, Czech Republic

Oldřich Mužík, Research Institute of Agricultural Engineering, Prague, Czech Republic

David Hartman, Head of IT department, Unicorn College, Prague, AND Institute of Computer Science, Academy of Science of the Czech Republic, AND Department of Applied Mathematics, Charles University, Prague, Czech Republic

Petr Bitala, Department of Fire Protection, Faculty of Safety Engineering, VŠB-Technical University of Ostrava, Czech Republic

Barbora Baudišová, Laboratory for Risk Research and Management, Faculty of Safety Engineering, AND Energy research center, VŠB-Technical University of Ostrava, Czech Republic

Jan Ptáček, Headmaster of the High School of Chemistry in Pardubice, Czech Republic

Jan Kamenický, Institute of Mechatronics and Computer Engineering, Faculty of Mechatronics, Informatics and Interdisciplinary studies, Liberec Technical University, Czech Republic

Lenka Hrušková, Institute of geochemistry, mineralogy and mineral resources, Faculty of Science, Charles University in Prague, Czech Republic

Václav Nevrlý, Institute of Thermomechanics, Academy of Sciences of the Czech Republic; Faculty of Safety Engineering, VŠB-Technical University of Ostrava, Czech Republic 